\title{
Breast Cancer: Rank Ligand Inhibition
}

\author{
Rupert Bartsch ${ }^{a, b} \quad$ Guenther G. Steger ${ }^{b}$ Michael Gnant ${ }^{c} \quad$ Reinhard Ziebermayr $^{a}$ \\ aDepartment of Medicine I (Centre for Haematology, Stem Cell Transplantation, Haemostasis and Medical Oncology), Academic Teaching \\ Hospital Elisabethinen, Linz, \\ bepartment of Medicine I and Cancer Centre, Clinical Division of Oncology, \\ 'Department of Surgery, Medical University of Vienna, Austria
}

\section{Key Words}

Bisphosphonates - Bone metastases - Denosumab .

Osteoporosis - Cancer treatment-induced bone loss

\section{Summary}

Breast cancer and bone health are closely linked. Early menopause induced by gonadotropin-releasing hormone analogues or chemotherapy as well as aromatase inhibitors reduce oestrogen levels, thereby causing cancer treatment-induced bone loss (CTIBL). Furthermore, bone metastases are commonly found in advanced disease. Current treatment options for bone lesions comprise systemic anti-tumour therapy, irradiation, surgery and bisphosphonates. The main mechanism of osteolysis, osteoclast activation, is induced by the RANK ligand and suppressed by osteoprotegerin (OPG). A human antibody targeting the RANK ligand, denosumab, had superior activity compared to OPG and was therefore further developed in the clinical setting. This article reviews clinical data on denosumab. Data were obtained by searching the Medline database and abstracts from the ASCO annual meeting, ASCO breast meeting, ECCO, ESMO, and the San Antonio Breast Cancer Symposium. Clinical trials have demonstrated that denosumab reduces markers of bone turnover, and suggest equal efficacy to bisphosphonates in reducing the rate of skeletal-related events. While overall fewer side effects were observed, a numerically increased rate of osteonecrosis of the jaw was reported. Denosumab was well tolerated, and clinical activity was similar to bisphosphonates in metastatic disease. Trials of denosumab in the prevention of CTIBL are ongoing.

\section{Schlüsselwörter \\ Bisphosphonate - Knochenmetastasen - Denosumab . Osteoporose $\cdot$ Therapiebedingter Knochenverlust}

\section{Zusammenfassung}

Brustkrebs und Knochengesundheit sind eng verbunden. Vorzeitige Menopause durch GnRH (gonadotropin-releasing hormone)-Analoga oder Chemotherapie sowie Aromatasehemmer führen über reduzierte Östrogenspiegel zu therapiebedingtem Knochenverlust (cancer treatmentinduced bone loss, CTIBL). Auch sind Knochenmetastasen beim metastasierten Brustkrebs häufig. Derzeitige Behandlungsoptionen umfassen systemische Antitumortherapien, Bestrahlung, orthopädische Eingriffe sowie Bisposphonate. Die Osteoklastenaktivierung, die zum Knochenabbau führt, wird durch den RANK-Liganden vermittelt und durch Osteoprotegerin (OPG) gehemmt. Ein Antikörper gegen den RANK-Liganden, Denosumab, erwies sich im klinischen Einsatz OPG überlegen. Dieser Artikel fasst klinische Daten zu Denosumab zusammen. Dazu wurden die Pubmed Medline, sowie Abstracts vom ASCO Annual Meeting, ASCO Breast, ECCO, ESMO, sowie dem San Antonio Breast Cancer Symposium durchsucht. Ergebnisse zeigen, dass Denosumab die Marker des Knochenumsatzes reduzieren kann. In Bezug auf die Vermeidung von Knochenkomplikationen war die Wirksamkeit mit Bisphosphonaten vergleichbar. Insgesamt traten weniger Nebenwirkungen auf, die Anzahl an Kieferosteonekrosen war jedoch numerisch erhöht. Denosumab zeichnete sich durch gute Verträglichkeit und Wirksamkeit bei Knochenmetastasen aus. Aktuell wird die Rolle von Denosumab zur Prävention von CTIBL in klinischen Studien untersucht.

\begin{tabular}{ll}
\hline KARGER & $\oplus$ 2010 S. Karger GmbH, Freiburg \\
Fax +497614520714 & Accessible online at: \\
Information@Karger.de & www.karger.com/brc \\
www.karger.com &
\end{tabular}




\section{Introduction}

\section{Breast Cancer and Bone Health}

Breast cancer and osteoporosis are among the most prevalent diseases in women $[1,2]$. They are closely linked to cancertreatment induced bone loss (CTIBL) [3]. Furthermore, breast cancer commonly metastasizes to bone [1, 4]; indeed, bone metastases are found in up to $60 \%$ of all patients with advanced stage disease [4].

\section{Cancer Treatment-Induced Bone Loss}

In premenopausal women, chemotherapy may induce ovarian failure [5]. Likewise, adjuvant endocrine therapy with gonadotropin-releasing hormone $(\mathrm{GnRH})$ analogues suppresses ovarian function. Eventually, this early reduction of normal oestrogen levels increases bone loss [6]. In postmenopausal women, aromatase is the main source of oestrogen production [7]; inhibition of aromatase with aromatase inhibitors (AIs) is superior to tamoxifen in the adjuvant setting [8]. Reduction of oestrogen blood levels by aromatase inhibition, on the other hand, confers bone loss [9]. This eventually translates into a higher fracture rates $(11 \%$ with AIs compared to $8 \%$ with tamoxifen) [10]. With growing awareness of those facts, clinical trials of CTIBL prevention with bisphosphonates were initiated. By now, it is well established that bisphosphonates inhibit CTIBL [6, 11]. This effect, however, might not translate into a reduction of fracture rates [12]. Denosumab, a monoclonal antibody targeting receptor activator of nuclear factorkappaB ligand (RANKL), was found to reduce the incidence of new vertebral fractures in patients on androgen deprivation for prostate cancer [13]. Trials of denosumab for prevention of CTIBL in breast cancer are currently ongoing [14].

\section{Bone Metastases in Breast Cancer}

As outlined, bone metastases are common in breast cancer; they are classified according to radiographic appearance as osteolytic, osteoblastic, or mixed [15], with the majority being osteolytic [16]. Possible complications such as hypercalcaemia, fractures, or spinal cord compressions may therefore occur. As a consequence of this, an increased need for local treatment such as surgery or radiotherapy to bone arises [17]. Complications and the need for local interventions are summarized by the term skeletal-related events (SREs) [18]. In clinical studies, biomarkers of bone turnover predicting for SREs (e.g. urinary-N-telopeptide/creatinine ratio, uNTx/Cr) are measured in order to assess activity of bone disease; their respective decrease is commonly used as surrogate for treatment efficacy [19].

\section{Current Treatment Options for Bone Metastases}

Besides local interventions, current treatment strategies for bone metastases comprise systemic anti-tumour therapy and bisphosphonates. Bisphosphonates block osteolysis by di- rectly inhibiting osteoclasts, highly specialized cells of bone resorption [20]. Due to its antiresorptive properties, bisphosphonates reduce SREs and cancer-associated bone pain [21].

\section{Regulation of Bone Metabolism}

\section{Regulation of Bone Resorption}

Bone resorption necessitates osteoclast activation. As early as 1980, it was suggested that osteoblasts might be involved in osteoclastogenesis [22]. An 'osteoclast-activating factor' produced by osteoblasts was hypothesized, whose nature remained elusive up until 1998 when RANKL was identified [23]. Osteoclasts themselves derive from osteoclast precursors (OCPs), cells of the mononuclear linage [24] and derivatives of pluripotent precursors in the bone marrow [25]. Increased numbers of such OCPs are responsible in part for bone resorption in multiple myeloma [26]. Bone resorption, as understood today, is regulated by the RANK/RANKL/OPG pathway consisting of 3 proteins: RANK, RANKL (which activates OCPs by binding to membrane-bound RANK), and its antagonist, osteoprotegerin (OPG) [27]. Those proteins are members of the tumour necrosis factor (TNF) receptor family of cytokines. Osteoblasts as well as bone marrow stromal cells secrete RANKL and monocyte colony-stimulating factor (MCSF) [28]. M-CSF is constitutively expressed; the relative levels of RANKL and OPG expression therefore control osteoclastogenesis [29].

\section{RANK Pathway in Osteolytic Metastases of Solid Cancers}

Complex interactions between tumour cells, bone matrix, and bone cells occur in lytic bone lesions, resulting in a vicious cycle of bone destruction [30]. In breast cancer, tumour cells secrete cytokines and growth factors such as parathyroid hormone-related peptide (PTHrP), IL-1, IL-6, IL-8, IL11, and TNF- $\alpha$, triggering upregulation of RANKL expression in osteoblasts and stromal cells [31-33]. In other malignancies (prostate cancer, multiple myeloma), tumour cells were found to express RANKL directly $[34,35]$. Furthermore, some cytokines (IL-1, IL-6, IL-8, TNF- $\alpha$ ) can stimulate osteoclastogenesis in a RANKL-independent manner [36, 37]. Resulting bone resorption again mobilizes growth factors from bone matrix (TGF- $\beta$, insulin-like growth factor, basic fibroblast growth factor, bone morphogenetic protein (BMP)) which in term promote tumour growth and support tumour cell survival [15, 16, 38] (fig. 1). Indeed, an animal model revealed that tumour cells directly adjacent to bone had a significantly higher proliferation rate [39]. OPG, on the other hand, was found to reduce osteoclastogenesis [35]. This was observed in co-culture systems wherein cancer cells induced other cells to express RANKL [32, 40]. Therefore, it seemed reasonable to develop compounds inhibiting the RANK/RANKL pathway. 


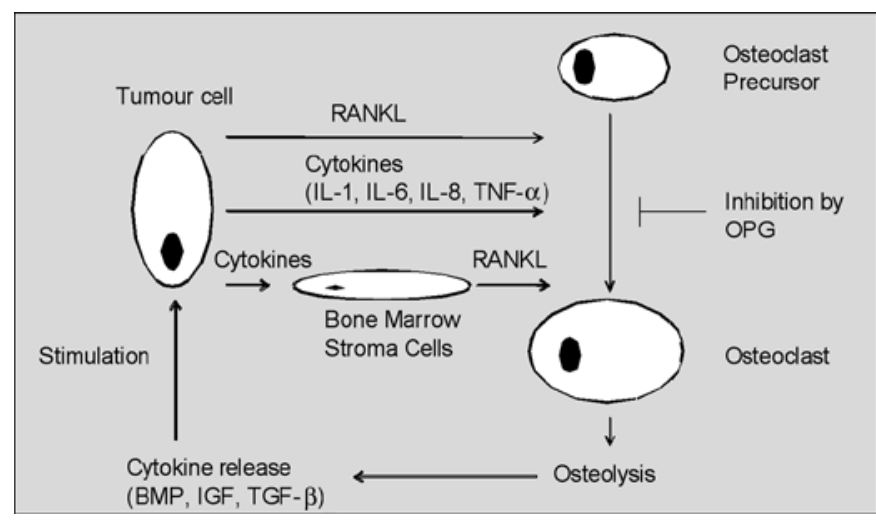

Fig. 1. Osteoclast activation in bone metastases $(\mathrm{BMP}=$ bone morphogenetic protein; IGF = insulin-like growth factor; IL = interleukin; OPG $=$ osteprotegerin; RANKL $=$ receptor activator of nuclear factor-kappaB ligand; TGF- $\beta=$ transforming growth factor $\beta$; TNF- $\alpha=$ tumour necrosis factor $\alpha$ ).

\section{Denosumab}

\section{Early Development}

Development of drugs targeting the RANK/RANKL pathway started with recombinant OPG (AMGN-0007). OPG was active and well tolerated in women with osteoporosis and lytic bone lesions [41, 42]. Yet denosumab (AMG162), a fully human antibody targeting RANKL, reduced levels of bone turnover markers to a greater extent. Therefore, further development of OPG was discontinued [43]. In phase I trials, different doses and schedules of denosumab and their respective effects on pharmacodynamics (PD), parmacokinetics $(\mathrm{PK})$, as well as uNTX were evaluated. In patients with postmenopausal osteoporosis, effects of denosumab were sustained for up to 6 months, allowing for an administration schedule similar to intravenous bisphosphonates [43]. Further studies were conducted in patients with breast cancer and multiple myeloma. No drug-related serious adverse events or antibodies against denosumab were observed [44, 45]. Based upon those early data, phase II studies of denosumab in postmenopausal osteoporosis, multiple myeloma, and metastatic solid tumours were initiated.

\section{Phase II Clinical Trials of Denosumab in Malignancies}

In a randomized phase II trial, 255 patients with metastatic breast cancer received different doses and schedules of denosumab or zoledronic acid. Primary study endpoint was reduction of uNTX/Cr. Denosumab and zoledronic acid yielded similar results; serious adverse events were reported in $9 \%$ of patients treated with denosumab as compared to $16 \%$ in the bisphosphonate group. According to PK/PD simulations, a dose of $120 \mathrm{mg}$ administered every 4 weeks was reported as the optimal schedule [46]. A recent update once again concluded that denosumab suppressed uNTX/Cr to the same extent as zoledronic acid [47]. Another phase II study was con- ducted in a mixed cancer population already receiving bisphosphonates for bone metastases. A total of 111 patients were randomized to denosumab or bisphosphonate continuation. The percentage of patients reaching uNTx levels $<50$ $\mathrm{nmol} / \mathrm{l}$ at week 13 was defined as primary study endpoint. This level was reached by $71 \%$ of patients on denosumab, as compared to $29 \%$ in the group with ongoing intravenous bisphosphonates $(\mathrm{p}<0.001)$. Rates of adverse events were similar between treatment groups [48].

\section{Phase II Clinical Trial of Denosumab in CTIBL}

In a trial of denosumab for the prevention of CTIBL, 252 patients with reduced bone mass receiving AIs for early breast cancer were randomized to denosumab (60 mg subcutaneously every 6 months) or placebo. Primary study endpoint was lumbar spine bone mineral density (BMD) after 1 and 2 years. In the denosumab group, BMD increased significantly over time (5.5 and $7.6 \%$ at 12 and 24 months, respectively; $\mathrm{p}<0.0001$ both time points). Treatment was well tolerated, and adverse events were similar between the denosumab and placebo group [49]. Based upon these results, phase III trials of denosumab in malignant bone disease were initiated. Other studies evaluated the role of denosumab in postmenopausal osteoporosis and CTIBL [14].

\section{Phase III Clinical Trials of Denosumab in Malignancies and CTIBL}

Currently, two phase III trials of denosumab in patients with bone metastases have reported respective results. In a trial of denosumab in a mixed cancer population (patients with breast or prostate cancer were excluded), the primary study endpoint, non-inferiority to zoledronic acid, was reached (hazard ratio (HR) 0.84 ; $95 \%$ confidence interval (CI) $0.71-0.98$; p = 0.0007 ) [50]. In a second large study conducted in breast cancer patients (Amgen 20050136; NCT00321464) who had not received prior treatment with intravenous bisphosphonates, a total of 2,046 patients were randomized to denosumab $120 \mathrm{mg}$ every 4 weeks or zoledronic acid. Preliminary results were presented at the 2009 European Cancer Conference and updated at the 2009 San Antonio Breast Cancer Symposium [51, 52]. Time to first SRE was significantly longer in the denosumab group (HR 0.82; 95\% CI 0.71-0.95; $\mathrm{p}<0.0001$ non-inferiority; $\mathrm{p}=0.001$ superiority). Denosumab was also significantly superior in delaying time to first radiation to bone (HR $0.74 ; 95 \%$ CI $0.59-0.94 ; \mathrm{p}=0.01)$ and time to first event of hypercalcaemia of malignancy (HR 0.82; 95\% CI 0.70-0.95; $\mathrm{p}=0.007)$. Overall, less adverse events were observed in the denosumab group, although, in contrast to phase II data, a similar rate of ONJ was reported. Results of NCT00321464 are summarized in table 1 . As preclinical as well as limited clinical data suggested a direct anti-tumour effect of zoledronic acid, it was carefully observed if denosumab had a detrimental effect on tumour progression. 
Table 1. Comparison of denosumab versus zoledronic acid in metastatic breast cancer $(n=2,046)$

\begin{tabular}{|c|c|c|c|}
\hline Endpoint & Hazard ratio & $95 \% \mathrm{CI}$ & $\mathrm{p}$ \\
\hline \multicolumn{4}{|l|}{ Primary endpoint } \\
\hline Time to first on-study SRE, non-inferiority & 0.82 & $0.71-0.95$ & $>0.0001$ \\
\hline \multicolumn{4}{|l|}{ Secondary endpoints } \\
\hline Time to first on-study SRE, superiority & 0.82 & $0.71-0.95$ & 0.01 \\
\hline Time to first and subsequent on-study SRE & 0.77 & $0.66-0.89$ & 0.001 \\
\hline Time to first radiation to bone & 0.74 & $0.59-0.94$ & 0.01 \\
\hline Time to first on-study SRE or HCM & 0.82 & $0.70-0.95$ & 0.007 \\
\hline Time to experiencing moderate or severe pain & 0.87 & $0.79-0.97$ & 0.009 \\
\hline Overall disease progression & 1.00 & $0.89-1.11$ & n.s. \\
\hline Overall survival & 0.95 & $0.81-1.11$ & n.s. \\
\hline Skeletal-related events & Denosumab & Zoledronic acid & $\mathrm{p}$ \\
\hline Total number of SREs, $n$ & 491 & 623 & n.a. \\
\hline Skeletal morbidity rate, mean (SREs per year, n) & 0.45 & 0.58 & 0.004 \\
\hline Overall AEs, n (\%) & $977(96)$ & $985(97)$ & \\
\hline Severe AEs, n (\%) & $453(44)$ & $471(46)$ & \\
\hline Acute phase reactions ${ }^{\mathrm{a}}, \mathrm{n}(\%)$ & $106(10.4)$ & $277(27.3)$ & \\
\hline AEs related to renal toxicity, n (\%) & $50(4.9)$ & $86(8.5)$ & \\
\hline Osteonecrosis of the jaw, n (\%) & $20(2.0)$ & $14(1.4)$ & \\
\hline Toothache, n (\%) & $57(5.6)$ & $37(3.7)$ & \\
\hline Hypocalcaemia, n (\%) & $56(5.5)$ & $34(3.4)$ & \\
\hline
\end{tabular}

While the studies were not powered for such endpoint analysis, available clinical data do not suggest impairment of oncologic outcomes in the respective denosumab groups.

In a randomized trial of denosumab versus placebo in patients on androgen deprivation therapy for prostate cancer, denosumab was associated with increased BMD and a lower rate of vertebral fractures, therefore preventing CTIBL [13]. A study of denosumab for the prevention of CTIBL in breast cancer conducted by the Austrian Breast and Colorectal Cancer Study Group (ABCSG-18; NCT00556374) is currently ongoing. Patients on adjuvant AIs without prior bisphosphonate exposure are randomized to denosumab or placebo; results of this trial will eventually clarify the role of denosumab in CTIBL prevention [14].

\section{Tolerability}

Denosumab was well tolerated in clinical trials, and side effects were in general mild and manageable (table 1). Still, due its specific mechanism of action, a number of concerns were raised. As the RANK pathway is a co-stimulatory pathway for T-cell activation, a higher risk for infectious diseases was anticipated [53]. In vivo studies, however, revealed no increased risk of bacterial infections [54] or altered virus clearance in response to influenza infections [55].

ONJ is a rare yet problematic side effect of bisphosphonate therapy. The highest incidence occurs with nitrogen bisphosphonates in cancer patients, although a number of cases have been reported in women on oral bisphosphonates for osteoporosis. Importantly, it was observed that dental surgical procedures further increase the risk. ONJ therefore may be caused by complete inhibition of normal bone turnover in conjuncture with traumatic bone lesions or infection [56]. In early clinical studies of RANKL inhibition, no cases of ONJ were observed. Phase III clinical trials, however, reported a numerically increased number of ONJ in the respective denosumab groups [52]. Therefore, the same safety recommendations apply.

Repeatedly, a direct anti-tumour effect of zoledronic acid was suggested in preclinical models [57]. In ABCSG-12, premenopausal patients on adjuvant endocrine therapy were randomly assigned to zoledronic acid or control. Here, significantly fewer recurrence events were observed in the bisphosphonate group [58]. Those findings are meanwhile supported by data from postmenopausal bone protection trials (ZOFAST; NCT00171314) [59]. Currently, there are no data on the effect of denosumab on breast cancer recurrence or progression; results from phase III trials, however, do not suggest an increased risk for tumour progression. An ongoing study (ABCSG 18; NCT00556374) is evaluating the role of denosumab in the prevention of CTIBL in postmenopausal patients receiving adjuvant endocrine therapy with AIs [14]. In this randomized phase III trial, recurrence-free survival is assessed as secondary endpoint. The D-CARE trial (study of denosumab as adjuvant treatment for women with high risk early breast cancer receiving neoadjuvant or adjuvant therapy; NCT01077154) even defined bone metastasis-free survival as primary study endpoint [14]. Together, those two trials will yield important insights into whether inhibition of the RANK pathway can ultimately improve recurrence-free survival. 


\section{Conclusion}

Currently, bisphosphonates are the standard of care for the treatment of breast cancer patients with bone metastases. Those drugs effectively reduce the number of SREs. Still, many patients will eventually develop SREs despite treatment; therefore, alternative treatment approaches are of value. Denosumab is a fully human antibody targeting RANKL. Phase III clinical trials suggest at least equal efficacy of denosumab and zoledronic acid. Denosumab was well tolerated and side effects were mild; still, the incidence of ONJ was numerically increased. Ongoing clinical studies are evaluating the potential role of denosumab for the prevention of CTIBL and its effect on tumour progression. In conclusion, inhibition of osteoclast activation by denosumab offers an effective and well tolerated treatment option in patients with bone metastases from breast cancer and other malignancies.

\section{Conflict of Interest}

Rupert Bartsch: advisory board Amgen; lecture honoraria: Novartis. Guenther G. Steger: advisory board Amgen; travel support: Amgen; Michael Gnant: advisory board Amgen, Novartis; consultant with Amgen, Novartis; lecture honoraria: Amgen, Novartis; research support: Amgen, Novartis.

\section{References}

1 American Cancer Society Facts and Figures 2009: www.cancer.org/docroot/STT/STT_O.asp (last accessed May 11th 2010).

2 Gralow JR, Biermann JS, Farooki A, Fornier MN, Gagel RF, Kumar RN, Shapiro CL, Shields A, Smith MR, Srinivas S, Van Poznak CH: NCCN Task Force Report: Bone Health in Cancer Care. J Natl Compr Canc Netw 2009;7(suppl 3):S1-S32.

$\checkmark 3$ Amir E, Ocaña A, Seruga B, Josse R, Clemons M: Medical oncology: zoledronic acid for breast cancer therapy-induced bone loss. Nat Rev Clin Oncol 2010;7:187-188

4 Coleman RE: Metastatic bone disease: clinical features, pathophysiology, and treatment strategies. Cancer Treat Rev 2001;27:165-176.

$\checkmark 5$ Hines SL, Mincey BA, Sloan JA, Thomas SP, Chottiner E, Loprinzi CL, Carlson MD, Atherton PJ, Salim M, Perez EA: Phase III randomized, placebo-controlled, double-blind trial of risedronate for the prevention of bone loss in premenopausal women undergoing chemotherapy for primary breast cancer. J Clin Oncol 2009;27:1047-1053.

6 Gnant MF, Mlineritsch B, Luschin-Ebengreuth G, Grampp S, Kaessmann H, Schmid M, Menzel C, Piswanger-Soelkner JC, Galid A, Mittlboeck M, Hausmaninger H, Jakesz R; Austrian Breast and Colorectal Cancer Study Group: Zoledronic acid prevents cancer treatment-induced bone loss in premenopausal women receiving adjuvant endocrine therapy for hormone-responsive breast cancer: a report from the Austrian Breast and Colorectal Cancer Study Group. J Clin Oncol 2007;25:820-828.

7 Dowsett M, Jones A, Johnston S, Jacobs S, Trunet $P$, Smith IE: In vivo measurement of aromatase inhibition by letrozol (CGS 20267) in postmenopausal women with breast cancer. Clin Cancer Res 1995;1:1511-1515.

8 Thürlimann B, Keshaviah A, Coates AS, Mouridsen H, Mauriac L, Forbes JF, Paridaens R, Castiglione-Gertsch M, Gelber RD, Rabaglio M, Smith I, Wardley A, Price KN, Goldhirsch A; Breast International Group (BIG) 1-98 Collaborative Group: A comparison of letrozole and tamoxifen in postmenopausal women with early breast cancer. N Engl J Med 2005;353:2727-2757.
9 Perez EA, Josse RG, Pritchard KI, Ingle JN, Martino S, Findlay BP, Shenkier TN, Tozer RG, Palmer MJ, Shepherd LE, Liu S, Tu D, Goss PE: Effect of letrozol versus placebo on bone mineral density in women with primary breast cancer completing 5 or more years of adjuvant tamoxifen: a comparison study to NCIC CTC MA.17. J Clin Oncol 2006;24:3629-3635.

10 Howell A, Cuzick J, Baum M, Buzdar A, Dowsett M, Forbes JF, Hoctin-Boes G, Houghton J, Locker GY, Tobias JS; ATAC Trialists' Group: Results of the ATAC (Arimidex, Tamoxifen, Alone or in Combination) trial after completion of 5 years' adjuvant treatment for breast cancer. Lancet 2005:365:60-62.

11 Van Poznak C, Hannon RA, Mackey JR, Campone M, Apffelstaedt JP, Clack G, Barlow D, Makris A, Eastell R: Prevention of aromatase inhibitorinduced bone loss using risedronate: the SABRE trial. J Clin Oncol 2010;28:967-975.

12 Valachis A, Polyzos NP, Gergoulias V, Mavroudis D, Mauri D: Lack of evidence for fracture prevention in early breast cancer bisphosphonate trials: a meta-analysis. Gynecol Oncol 2010;117:139-145.

13 Smith MR, Egerdie B, Hernández Toriz N, Feldman R, Tammela TL, Saad F, Heracek J, Szwedowski M, Ke C, Kupic A, Leder BZ, Goessl C; Denosumab HALT Prostate Cancer Study Group: Denosumab in men receiving androgendeprivation therapy for prostate cancer. N Engl J Med 2009;361:7445-7455.

14 Clinical Trials: www.clinicaltrial.gov (last accessed May 12th 2010).

15 Roodman GD: Mechanisms of bone metastases. N Engl J Med 2004:350:1655-1664.

16 Yin JJ, Pollock CB, Kelly K: Mechanisms of cancer metastasis to the bone. Cell Res 2005;15:57-62.

17 Mundy GR: Metastasis to bone: causes, conse quences and therapeutic opportunities. Nat Rev Cancer 2002:2:584-593.

18 Ross JR, Saunders Y, Edmonds PM, Patel S, Broadley KE, Johnston SR: systematic review or the role of bisphosphonates on skeletal morbidity in metastatic breast cancer BMJ 2003:327:469-474.

19 Brown JE, Thomson CS, Ellis SP, Gutcher SA, Purohit OP, Coleman RE: Bone resorption predicts for skeletal complications in metastatic bone disease. Br J Cancer 2003;89:2031-2037.
0 Teitelbaum SL: Bone resorption by osteoclasts. Science 2000;289:1504-1508.

21 Cascinu S, Graziano F, Alessandroni P, Ligi M, Del Ferro E, Rossi D, Ficarelli R, Catalano G: Different doses of pamidronate in patients with painful osteolytic bone metastases. Support Care Cancer 1998;6:139-143.

22 Rodan GA, Martin TJ: Role of osteoblasts in hormonal control of bone resorption: a hypothesis Calcif Tissue Int 1981;33:349-351.

23 Geusens P: Emerging treatments for postmenopausal osteoporosis - focus on denosumab. Clin Interv Aging 2009;4:241-250.

24 Massey HM, Flanagan AM: Human osteoclasts derive from CD14-positive monocytes. Br J Hadematol 1999;106:167-170.

25 Shimamura.T, Amizuka N, Li M, Freitas PH White JH, Henderson JE, Shingaki S, Nakajima T, Ozawa H: Histological observations on the microenvironment of osteolytic bone metastases by breast carcinoma cell line. Biomed Res 2005;26:159-172.

26 Gregoretti MG, Bergui L, Aragno M, Cremona O, Marchisio PC, Caligaris-Cappio F: Osteoclast precursors circulate in the peripheral blood of patients with aggressive multiple myeloma. Leukemia 1995;9:1392-1397.

27 Vega D, Maalouf NM, Sakhaee K: The role of receptor activator of nuclear factor-kappaB (RANK)/ RANK ligand/osteoprotegerin: clinical implications. J Clin Endocrinol Metab 2007;92:4514-4521.

28 Suda T, Takahashi N, Udagawa N, Jimi E, Gillespie MT, Martin TJ: Modulation of osteoclast differentiation and function by the new members of the tumor necrosis factor receptor and ligand families. Endocr Rev 1999;20:345-357.

29 Nakagawa N, Kinosaki M, Yamaguchi K, Shima N, Yasuda H, Yano K, Morinaga T, Higashio K RANK is the essential signaling receptor for osteoclast differentiation factor in osteoclastogenesis. Biochem Biophys Res Commun 1998;253:395-400.

30 Giuliano N, Colla S, Rizzoli V: Update on the pathogenesis of osteolysis in multiple myeloma patients. Acta Biomed 2004;75:143-152.

31 Thomas RJ, Guise TA, Yin JJ, Elliott J, Horwood NJ, Martin TJ, Gillespie MT: Breast cancer cells interact with osteoblasts to support osteoclast formation. Endocrinology 1999;140:4451-4458. 
-32 Chikatsu N, Takeuchi Y, Tamura Y, Fukumoto S, Yano K, Tsuda E, Ogata E, Fujita T: Interactions between cancer and bone marrow cells induce osteoclast differentiation factor expression and osteoclast-like cell formation in vitro. Biochem Biophys Res Comm 2000;267:632-637

33 Kitazawa S, Kitazawa R: RANK ligand is a prerequisite for cancer-associated osteolytic lesions. J Pathol 2002;198:228-236.

-34 Brown JM, Corey E, Lee ZD, True LD, Yun TJ, Tondravi M, Vessella RL: Osteoprotegerin and RANK ligand expression in prostate cancer. Urology 2001;57:611-616

35 Farrugia AN, Atkins GJ, To LB, Pan B, Horvath N, Kostakis P, Findlay DM, Bardy P, Zannettino $\mathrm{AC}$ : Receptor activator of nuclear factor- $\mathrm{\kappa B}$ ligand expression by human myeloma cells mediates osteoclast formation in vitro and correlates with bone destruction in vivo. Cancer Res 2003;63:5438-5445

36 Bendre MS, Margulies AG, Walser B, Akel NS, Bhattacharrya S, Skinner RA, Swain F, Ramani V, Mohammad KS, Wessner LL, Martinez A, Guise TA, Chirgwin JM, Gaddy D, Suva LJ: Tumour derived interleukin-8 stimulates osteolysis independent of the receptor activator of nuclear factor-kappa B ligand pathway. Cancer Res 2005; 65:11001-11009.

37 Kudo O, Sabokbar A, Pockok A, Itonaga I, Fujikawa Y, Athanasou NA: Interleukin-6 and interleukin-11 support human osteoclast formation by a RANKL-independent mechanism. Bone 2003;32:1-7.

38 Hauschka PV, Mavrakos AE, Iafrati MD, Doleman SE, Klagsbrun M: Growth factors in bone matrix. Isolation of multiple types by affinity chromatographyon heparin-sepharose. J Biol Chem 1986:261:12665-12674.

39 Kostenuik PJ, Singh G, Suyama KL, Orr FW: A quantitative model for spontaneous bone metastasis: evidence for a mitogenic effect of bone on Walker 256 cancer cells. Clin Exp Metastasis 1992;10:403-410.

40 Okada T, Akikusa S, Okuno H, Kodaka M: Bone marrow metastatic myeloma cells promote osteoclastogenesis through RANKL on endothelial cells. Clin Exp Metastasis 2003;20:639-646.

41 Bekker PJ, Holloway D, Nakanishi A, Arrighi M, Leese PT, Dunstan CR: The effect of a single dose of osteoprotegerin in postmenopausal women. J Bone Miner Res 2001;16:348-360.

42 Body JJ, Greipp P, Coleman RE, Facon T, Geurs F, Fermand JP, Harousseau JL, Lipton A, Mariette X, Williams CD, Nakanishi A, Holloway D, Martin SW, Dunstan CR, Bekker PJ: A phase I study of AMGN-0007 a recombinant osteoprotegerin construct, in patients with multiple myeloma or breast carcinoma related bone metastases. Cancer 2003;97:887-892.
43 Bekker PJ, Holloway DL, Rasmussen AS, Murphy R, Martin SW, Leese PT, Holmes GB, Dunstan CR, DePaoli AM: A single-dose placebo-controlled study of AMG 162, a fully human monoclonal antibody to RANKL, in postmenopausal women. J Bone Miner Res 2004;19:1059-1966.

44 Body JJ, Facon T, Coleman RE, Lipton A, Geurs F, Fan M, Holloway D, Peterson MC, Bekker PJ: A study of the biological receptor activator of nuclear factor-kappaB ligand inhibitor, denosumab, in patients with multiple myeloma or bone metastases from breast cancer. Clin Cancer Res, 2006;12:1221-1228.

45 Peterson MC, Jang G, Kim W, Gurrola E, Kinsey A, Dansey R: Selection of a phase 3 dose regimen for denosumab based on pharmacokinetic (PK), pharmacodynamic (PD), and safety data from multiple subcutaneous (SC) dosing regimens in breast cancer patients (pts) with bone metastases (BM). J Clin Oncol 2006;24(suppl 18):abstr 3086.

46 Lipton A, Steger GG, Figueroa J, Alvarado C, Solal-Celigny P, Body JJ, de Boer R, Berardi R, Gascon P, Tonkin KS, Coleman R, Paterson AH, Peterson MC, Fan M, Kinsey A, Jun S: Randomized active-controlled phase II study of denosumab efficacy and safety in patients with breast cancer-related bone metastases. J Clin Oncol 2007;25:4431-4437.

47 Lipton A, Steger GG, Figueroa J, Alvarado C, Solal-Celigny P, Body JJ, de Boer R, Berardi R, Gascon P, Tonkin KS, Coleman RE, Paterson AH, Gao GM, Kinsey AC, Peterson MC, Jun S: Extended efficacy and safety of denosumab in breast cancer patients with bone metastases not receiving prior bisphosphonate therapy. Clin Cancer Res 2008;14:6690-6696.

48 Fizazi K, Lipton A, Mariette X, Body JJ, Rahim Y, Gralow JR, Gao G, Wu L, Sohn W, Jun S: Randomized phase II trial of denosumab in patients with bone metastases from prostate cancer, breast cancer, or other neoplasms after intravenous bisphosphonates. J Clin Oncol 2009;27:1564-1571.

49 Ellis GK, Bone HG, Chlebowski R, Paul D, Spadafora S, Fan M, Kim D: Randomized trial of denosumab in patients receiving adjuvant aromatase inhibitors for nonmetastatic breast cancer. J Clin Oncol 2008;26:4875-4882.

50 Henry D, von Moos R, Vadhan-Raj S, Hungria V, Spencer A, Hirsh V, Wang J, Jun S, Yeh H, Dansey R: A double-blind, randomized study of denosumab versus zoledronic acid for the treatment of bone metastases in patients with advanced cancer (excluding breast and prostate cancer) or multiple myeloma. Eur J Cancer 2009;7(suppl 3): abstr 20LBA.
51 Stopeck A, Body JJ, Fujiwara Y, Lipton A, Steger GG, Viniegra M, Fan M, Braun A, Dansey R, Jun S: Denosumab versus zoledronic acid for the treatment of breast cancer patients with bone metastases: results of a randomized phase 3 study. Eur J Cancer 2009;7(suppl 3):abstr 2LBA.

52 Stopeck A, de Boer R, Fujiwara Y, Tonkin K, Yardley D, Fan M, Jun S, Dansey R, Braun A: A comparison of denosumab versus zoledronic acid for the prevention of skeletal-related events in breast cancer patients with bone metastases. Cancer Res 2009;69(suppl 24):abstr 22.

53 Wong BR, Rho J, Arron J, Robinson E, Orlinick J, Chao M, Kalachikov S, Cayani E, Bartlett FS 3rd, Frankel WN, Lee SY, Choi Y: TRANCE is a novel ligand of the tumor necrosis factor receptor family that activates c-Jun N-terminal kinase in T cells. J Biol Chem 1997;272:25190-25194.

54 Stolina M, Guo J, Faggioni R, Brown H, Senaldi G: Regulatory effects of osteoprotegerin on cellular and humoral immune responses. Clin Immunol 2003;109:347-354

55 Miller RE, Branstetter D, Armstrong A, Kennedy B, Jones J, Cowan L, Bussiere J, Dougall WC: Receptor activator of NF- B ligand inhibition suppresses bone resorption and hypercalcemia but does not affect host immune response to influenza infection. J Immunol 2007;179:266-274.

56 Woo SB, Hellstein JW, Kalmar JR: Systematic review: bisphosphonates and osteonecrosis of the jaws. Ann Intern Med 2006;144:753-761.

57 Winter MC, Holen I, Coleman RE: Exploring the anti-tumour activity of bisphosphonates in early breast cancer. Cancer Treat Rev 2008;34:452-475.

58 Gnant M, Mlineritsch B, Schippinger W, LuschinEbengreuth G, Pöstlberger S, Menzel C, Jakesz R, Seifert M, Hubalek M, Bjelic-Radisic V, Samonigg $\mathrm{H}$, Tausch $\mathrm{C}$, Eidtmann $\mathrm{H}$, Steger G, Kwasny W, Dubsky P, Fridrik M, Fitzal F, Stierer M, Rücklinger E, Greil R; ABCSG-12 Trial Investigators: Endocrine therapy plus zoledronic acid in premenopausal breast cancer. N Engl J Med 2009;360:6796-6791.

59 Eidtmann H, de Boer R, Bundred N, LlombartCussac A, Davidson N, Neven P, von Minckwitz G, Miller J, Schenk N, Coleman R: Efficacy of zoledronic acid in postmenopausal women with early breast cancer receiving adjuvant letrozole: $36-$ month results of the ZO-FAST Study. Ann Oncol 2010; Epub ahead of print 